\title{
Choosing of Brinjal Parents for Future Breeding Aiming at Bacterial Wilt Disease Tolerance
}

\author{
B. Lalramhlimi ${ }^{1}$, Tithi Dutta ${ }^{1}$, Imtinunsang Jamir ${ }^{2}$, Praveen Kumar Maurya ${ }^{1}$, \\ Tridip Bhattacharjee ${ }^{1}$, Swadesh Banerjee ${ }^{1}$, Soumitra Chatterjee ${ }^{2}$, \\ Asit Kumar Mandal ${ }^{3}$ and Arup Chattopadhyay ${ }^{1^{*}}$
}

\author{
${ }^{1}$ Department of Vegetable Science, Faculty of Horticulture, Bidhan Chandra Krishi \\ Viswavidyalaya, Mohanpur-741252, Nadia, West Bengal, India \\ ${ }^{2}$ Department of Agricultural Economics, Faculty of Agriculture, Bidhan Chandra Krishi \\ Viswavidyalaya, Mohanpur-741252, Nadia, West Bengal, India \\ ${ }^{3}$ Department of Plant Pathology, Faculty of Agriculture, Bidhan Chandra Krishi \\ Viswavidyalaya, Mohanpur-741252, Nadia, West Bengal, India
}

*Corresponding author

\section{Keywords \\ Brinjal, Diversity, Variablity, PCA, \\ Ralstonia \\ solanacearum}

Article Info

Accepted:

17 May 2019

Available Online:

10 June 2019

\section{A B S T R A C T}

Brinjal production is threatened by bacterial wilt caused by Ralstonia solanacearum in the developing world. Evaluation in search of best performing genotypes against bacterial wilt disease and incorporating their genes in commercial cultivars is an effective attempt to the problem. Studies on genetic variability and heritability, along with degree of association between the various characters and direct effects of yield contributing characters on total yield, is of paramount significance in framing an appropriate breeding strategy. The proper choice of parent based on genetic divergence is a pre-requisite in plant breeding programme. In the present study reactions of 23 brinjal genotypes, in terms of bacterial wilt incidence differed at different days after transplanting (DAT). Thirteen genotypes showed resistant reactions, five genotypes were categorized as moderately resistant, and two genotypes each exhibited moderately susceptible and susceptible reaction up to 90 DAT. Resistant genotypes had comparatively lower mean fruit weight than other categorized groups, revealing the fact that small fruited genotypes are linked with disease resistance. High heritability coupled with high genetic advance was recorded in bacterial wilt incidence and other important traits indicating that the selection among the genotypes can bring about significant improvement in disease tolerance due to presence of additive genes in trait. The absence of relationship between genetic diversity and geographical distance indicated that selection of genotypes for hybridization should be based on genetic divergence rather than geographic diversity. Based on multivariate analysis and average values three elite brinjal genotypes 16/BRBW RES-2, 2012/BRBW RES-5 and 2012/BRBW RES-6, which had recorded high bacterial wilt resistance coupled with diverse horticultural traits, could be utilized as donor parents either for developing hybrids or to isolate promising lines, in segregating generation, resistant to this disease. 


\section{Introduction}

The pride of farmers, native to India, exhibiting wide diversity is the brinjal (Solanum melongena L.) possessing high production potential and belongs to every household kitchen throughout the year. India is one of the largest brinjal producing countries in the world covering an area of 0.66 million hectares with a production of 12.51 million tones and a productivity of $18.96 \mathrm{t} / \mathrm{ha}$. West Bengal is the forerunner in brinjal production (30.03 lakh tonnes) with productivity of 18.53 t/ha (Anonymous, 2017).

However, successful cultivation is threatened by the attack of several insect pests, devastating diseases and growing of low yielding local types. Among plant diseases, soil-borne diseases are considered to be more limiting than seed-borne or air-borne diseases in the production of many crops and account for $10-20 \%$ of yield losses annually (USDA, 2003). Bacterial wilt, a soil-borne disease caused by Ralstonia solanacearum (Yabucchi et al., 1995) is a major limiting factor throughout tropical, sub-tropical and temperate regions of the world (Hayward, 1991). The bacterium can infect over 450 hosts and cause loss in yield up to $90 \%$ in solanaceous vegetables (Elphinstone, 2005; Wicker et al., 2007; Yuliar et al., 2015). In India, this disease is a serious threat in parts of Kerala, Orissa, Karnataka, Maharashtra, Madhya Pradesh and West Bengal (Rao et al., 1976). Among solanaceous vegetables brinjal is more susceptible with yield losses ranging from 65 to $70 \%$ (Das and Chattopadhyay, 1953). Sudden wilting of the plant at flowering stage followed by yellowing of foliage and stunted plant growth are the characteristic synptoms (Kelman, 1953; Rai et al., 1975) associated with brownish discoloration and rotting of vascular tissues (Smith, 1920). Initially this disease is regarded as $R$. solanacearum species complex (RSSC) due to inclusion of a large number of genetic groups (Gillings and Fahy, 1994). Then RSSC is subdivided into five phylotypes viz., phylotype I strains originate from Asia, phylotype IIA strains from the north of Latin America and the Caribbean, phylotype IIB strains from South America, phylotype III strains from Africa, and phylotype IV strains from Indonesia, Australia, and Japan (Fegan and Prior, 2005). We need to fine tune our understanding with regard to molecular and genetic bases of resistance controlling the diversity of RSSC strains in order to breed brinjal for resistance to bacterial wilt. Three resistance QTLs (EBWR2, EBWR14, and $E B W R 9$ ) control strains belonging to one or more phylotypes. By combining three resistance QTLs, breeders could able to develop varieties with a large spectrum of bacterial wilt resistance (Salgon et al., 2017). Though resistance to bacterial wilt has been studied in several crops, especially tomato, scanty published works on bacterial wilt resistance in eggplant genotypes are available (Chaudhary and Sharma, 2000; Hussain et al., 2005; Mondal et al., 2013; Gopalakrishnan et al., 2014).

Managing disease using appropriate farming practices needs further development and adaptation (Grimault and Prior, 1990). Hence, growing of resistant varieties could be an effective approach to the problem. Growing resistant brinjal is a durable, eco-friendly and effective control of the disease. Availability of and access to diverse genetic sources will ensure successful crop improvement programmes. Unfortunately, resistance reaction of commercial varieties is known to fluctuate both geographically and over time due to genetic variability of strains of the pathogens as well as the difference in the environments. So, it is necessary to evaluate different accessions in local conditions against the $R$. solanacearum. Therefore 
extensive collection, characterization, evaluation for superior genotypes resistant to biotic/abiotic stresses and conservation of species diversity assumes great priority in crop improvement programmes of brinjal. Lack of resistance source of this disease in brinjal has forced breeders to look into the wild species (Solanum torvum) which have stable and reliable sources of resistance to bacterial wilt. However, the transfer of resistance from wild relatives is difficult by conventional breeding method to produce subsequent generations having good quality fruits. Hence, continuous search for new sources of resistance for the development of varieties/hybrids with higher level of resistance against bacterial wilt disease should be the prime objective.

Genetic improvement of any crop mainly depends on the amount of genetic variability present in the population and the germplasm serves as a valuable source of base population and provide scope for wide variability (Gavade and Ghadage, 2015). A good scope of improvement in economic traits relies on the extent of natural variation present in various characters among the genotypes. Variability is a combined measure of genetic and environmental causes. Variability parameters like genotypic and phenotypic coefficient of variations, heritability and genetic advance, along with degree of association between the various characters and direct effect of yield contributing characters on total yield, is of paramount significance in framing an appropriate breeding strategy that focus on exploiting the inherent variability that remains unaltered by environmental conditions among genotypes, which is more useful for exploitation in selection and hybridization. The proper choice of parent based on genetic divergence is a pre-requisite in plant breeding programme. In eastern part of India, very less number of bacterial wilt tolerant hybrids developed so far in brinjal vis-à-vis the developed hybrids are not so popular with regard to fruit quality among the growers. Evaluation in search of best performing genotypes against bacterial wilt disease and incorporating their genes in commercial cultivars is an effective attempt to the problem.

Keeping in view the present study was undertaken to determine the extent of variability existing in the genotypes, to identify important selection indices and to select diverse genotype(s) that can be utilized in resistant breeding to retrieve potential high yielding lines resistant to bacterial wilt disease.

\section{Materials and Methods}

\section{Plant material and field growing}

Twenty-three genotypes of brinjal, collected from different sources were tested and evaluated under All India Coordinated Research Project on Vegetable Crops, Bidhan Chandra Krishi Viswavidyalaya, Kalyani, Nadia, West Bengal, India situated at $23.5^{\circ} \mathrm{N}$ latitude and $89^{\circ} \mathrm{E}$ longitude with a mean sea level of $9.75 \mathrm{~m}$. Seed beds were prepared in a sandy loam soil and were $20 \mathrm{~cm}$ high and 1.0 $\mathrm{m}$ wide. Weathered cowdung manure at 4 $\mathrm{kg} / \mathrm{m}^{2}$ was mixed into the beds. Beds were drenched with a $4 \%$ formaldehyde solution and covered with a clear polythene sheet for 10 days to avoid damping off disease. Seed, after treatment with Thiram $\left(3 \mathrm{~g} \mathrm{~kg}^{-1}\right.$ of seed), were sown during the 3rd week of July, 2017 at a depth $1 \mathrm{~cm}$, were $5 \mathrm{~cm}$ apart, and covered with finely sieved well-rotted leaf mold (leaves left to decompose for two year) to add organic matter and to prevent the soil from drying. After sowing, beds were covered with straw until germination which normally takes five to seven days and hand watered everyday up to $2^{\text {nd }}$ week of August. Nursery beds were 
covered with $200 \mu \mathrm{m}$ ultraviolet (UV)stabilized clear polyethylene film supported by bamboo poles with open sides to protect seedlings from rain and direct sunlight. Seedlings were hardened by withholding water 4 days before transplanting. Thirty-day old seedlings were transplanted in sick field pre-inoculated with $R$. solanacearum during $3^{\text {rd }}$ week of August following Randomized Block Design with three replications.

The population of $R$. solanacearum in the sick bed soil was estimated $8.46 \times 10^{8} \mathrm{cfu} / \mathrm{g}$ soil and soil $\mathrm{pH}$ was 6.5 . The size of the experimental plot was $4.5 \mathrm{~m} \times 4.2 \mathrm{~m}$ for each replication. The plant to plant and row to row distances were $75 \mathrm{~cm}$ and $60 \mathrm{~cm}$, respectively accommodating 42 plants per plot. A fertilizer dose of $150 \mathrm{~kg} \mathrm{~N}$ (urea), $75 \mathrm{~kg} \mathrm{P}$ (single super phosphate) and $75 \mathrm{~kg} \mathrm{~K}$ (muriate of potash) along with 10 tons of $\mathrm{FYM} / \mathrm{ha}$ were incorporated in the soil as per schedule (Chattopadhyay et al., 2011).

The bacterium, $R$. solanacearum, was isolated from diseased brinjal plants showing typical bacterial wilt symptoms on Triphenyltetrazolium chloride (TZC) medium. The seedlings of 23 brinjal genotypes were injured with sterilized knife and immersed in bacterial suspension containing Ralstonia solanacearum population of $1 \times 10^{8} \mathrm{cfu} / \mathrm{g}$ prior to transplanting into the main sick field. After inoculation, the plants were watered at alternate days and symptom of bacterial wilt was observed.

\section{Data recording}

The wilt symptoms and wilted plants were recorded at 30 days after transplanting (DAT), 60 DAT and 90 DAT and graded on a $0-5$ scale of Winstead and Kelman (1952) with some modifications. The genotypes were classified into five different groups (Table 1) according to percentage of wilted plants (PWP) as reported by Hussain et al., (2005).

Observations were also taken from ten randomly selected plants with uniform fruits from each plot for qualitative characters fruit colour, calyx colour, fruit shape, and quantitative characters fruit length $(\mathrm{cm})$, fruit diameter $(\mathrm{cm})$, fruit weight $(\mathrm{g})$, number of fruit per plant and fruit yield per plant $(\mathrm{kg})$. The average values for each genotype in each replication for the traits studied were used for further statistical analysis.

\section{Statistical analyses}

Analysis of variance for the studied traits was analysed as per Panse and Sukhatme (1967). Genotypic and phenotypic coefficients of variation were calculated using the formulae of Burton (1952). Broad sense heritability was calculated as per Lush (1940) and genetic advance was estimated by the method of Johnson et al., (1955). Categorization of genotypic coefficient of variation (GCV), phenotypic coefficient of variation (PCV) and genetic advance (GA) were done as per Sivasubramanian and Menon (1973) and heritability by Johnson et al., (1955). Phenotypic and genotypic correlation coefficients were computed as per Johnson et al., (1955). Path analysis was carried out as per Dewey and Lu (1959). D ${ }^{2}$ statistic was used for assessing the genetic divergence between populations (Mahalanobis, 1936). The grouping of the populations was done by using Tocher's method as described by Rao (1952). Hierarchical cluster analysis was performed with the same genotypes to observe degree of association according to characteristics expressed in a dendrogram (Ward, 1963). Principal component analysis (PCA), to identify the factor dimension of the data, was used to summarize varietal information in a reduced number of factors for selection of the best performing 
genotype(s). Statistical analyses were done using SAS 9.3 Professional Version and SPSS Professional Version 13.0.

\section{Results and Discussion}

\section{Reaction of genotypes against bacterial wilt disease}

Brinjal genotypes were screened against Ralstonia solanacearum Race-I, Biovar 3. Wilting of plants was observed and the number of wilted plants was counted at 30 DAT, 60 DAT and 90 DAT (Table 2). Disease reactions were recorded based on the percentage of wilted plants from total population of 42 plants using the scale. Most of the researchers (Hussain et al., 2005; Rahman et al., 2011) have relied upon screening techniques of brinjal genotypes against bacterial wilt disease on the basis of percent disease incidence at different DAT. Reactions of different genotypes, in terms of incidence values of bacterial wilt differed at different DAT of brinjal. Normally, under field conditions, wilt symptom appears at the time of flowering, which is approximately 30 to 40 days after transplanting. Typical wilting symptom was first observed at 30 DAT in genotypes 16/BRBW RES-4, 16/BRBW RES5, 16/BRBW RES-6, 16/BRBW RES-8, 13/BRBW/RES-1, 13/BRBW/RES-2, 13/BRBW/RES-3, PPL, 2012/BRBW RES-2, 2012/BRBW RES-4, 2012/BRBW RES-6, Arka Nidhi and Arka Kusumakar in varying degrees which escalated with increase in days while there was no symptom in genotypes 16/BRBW RES-1, 16/BRBW RES-2, 16/BRBW RES-3, 16/BRBW RES-7, 13/BRBW/RES-4, SM-6-7, 2012/BRBW RES-1，2012/BRBW RES-3，2012/BRBW RES-5 and 2012/BRBW RES-7 at 30 DAT. The ooze test showed the presence of xylem associated bacteria in plants of infected genotypes at 30 DAT. The incidence values among genotypes were lower (less than 10.00
\%) in 2012/BRBW RES-5, 2012/BRBW RES-1, 16/BRBW RES-3, 13/BRBW/RES-4, 2012/BRBW RES-2, 2012/BRBW RES-3, 2012/BRBW RES-7, SM-6-7, 13/BRBW/RES-3， 2012/BRBW RES-4, 16/BRBW RES-1 and 2012/BRBW RES-6 and no incidence was recorded in 16/BRBW RES-2 up to 60 DAT. Thirteen genotypes 16/BRBW RES-1, 16/BRBW RES-2, 16/BRBW RES-3, 16/BRBW RES-5, 16/BRBW RES-7, 13/BRBW/RES-2, 13/BRBW/RES-3, 13/BRBW/RES-4, SM-67, 2012/BRBW RES-1, 2012/BRBW RES-3, 2012/BRBW RES-5 and Arka Nidhi showed resistant reactions with less than $20 \%$ plants wilting, five genotypes 16/BRBW RES-8, 13/BRBW/RES-1, 2012/BRBW RES-4, 2012/BRBW RES-6 and 2012/BRBW RES-7 were categorized as moderately resistant with 21 - 40\% plants wilting, two genotypes 16/BRBW RES-6 and PPL exhibited moderately susceptible with $41-60 \%$ plants wilting, whereas 16/BRBW RES-4 and Arka Kusumakar showed susceptible with $61-80 \%$ plants wilting at 90 DAT. The incidence value was lowest in 2012/BRBW RES-5 (6.35 \%) which was statistically different from 16/BRBW RES-2 (8.33\%) and highest in Arka Kusumakar $(77.78 \%)$ up to 90 DAT (Table 2).

The resistance exhibited by various genotypes may be due to the secondary metabolism of polyphenols, and the higher concentration of steroidal glycoalkaloids present in resistant plants, thereby preventing bacterial movement into the vicinity of the plant system as observed by Vasse et al., (2005). Further, Prior et al., (1994) reported that inhibitor extracts tyloses and gums in resistant plants act like filters, thereby preventing bacterial movement within a plant system. In previous studies, Hazra and Som (1999); Geetha and Peter (1993) and Ponnuswami (1999) also found varieties SM-6-7 and Arka Nidhi to be resistant in different environments. Host 
resistance responses can be affected by environmental factors and the race and biovar. Ralstonia solanacearum causes lethal wilting disease in more than 200 plant species (Denny, 2000), while more than 450 plant species were listed as host plants for $R$. solanacearum including many important and economic crops (Hayward, 1991). The reason for these highly different and heterogeneous responses to the bacterial pathogen is not obvious; nevertheless it is assumed that specific pathogenic strains for certain hosts may have evolved only in certain parts of the world and are not found elsewhere or these hosts may only be susceptible where a number of environmental factors such as temperature, rainfall, soil type, inoculums and other soil biological factors are conductive to disease expression coincide (Hayward, 1991). Hanson et al., (1996) while studying the field reaction of tomato lines to different strains of $R$. solanacearum found that in Malaysia and Taiwan most of the tomato lines were resistant, but in the Philippines and Indonesia they were susceptible. This indicates that it is necessary to evaluate different accessions in local conditions against the $R$. solanacearum.

Resistant genotypes that possess suitable horticultural traits are a breeder's concern in crop improvement programme especially in disease prone areas. Fruit yield of genotypes varied from $241.46 \mathrm{q} / \mathrm{ha}$ (Arka Nidhi) to 308.64 (16/BRBW RES-2) among resistant genotypes and 120.27 q/ha (2012/BRBW RES-2) to $250.37 \mathrm{q} / \mathrm{ha}$ (16/BRBW RES-8) among moderately resistant genotypes (Table $2)$. The highest fruit yield was recorded in 16/BRBW RES-2 (308.64 q/ha) followed by 16/BRBW RES-7 (296.42 q/ha) and 16/BRBW RES-3 (293.21 q/ha). Despite the genotype 2012/BRBW RES-5 exhibited the lowest disease incidence, but it ranked $8^{\text {th }}$ in respect to yield potential. It can be concluded that genotype with low incidence of bacterial wilt disease does not always perform better with respect to yielding ability. The lowest fruit yield was recorded in Arka Kusumakar (SC) with only $80.88 \mathrm{q} / \mathrm{ha}$ and had highest disease incidence of $77.78 \%$ followed by PPL $(57.10 \%)$ with $114.42 \mathrm{q} / \mathrm{ha}$ yield.

The genotypes varied greatly in qualitative parameters such as fruit colour, calyx color and fruit shape (Table 3). Genotypes with high yield coupled with low disease incidence have purple colour fruits with green calyx which are most appealing characters from consumers' point of view particularly in eastern India. In view of changing local preference for colour, shape, taste, etc., it is not possible to have one common cultivar to suit different localities of a region. It is, therefore, necessary to improve the locally preferred cultivars or their utilization to develop new hybrid combinations for high yield, quality, disease tolerance, consumer acceptability and to meet diverse taste of local people.

Genotypes were highly significant for different fruit characters under study (Table 4). Fruit length of genotypes varied greatly $(9.52 \mathrm{~cm}$ to $27.45 \mathrm{~cm})$, the maximum being in 2012/BRBW RES-6 while, the minimum was observed in 16/BRBW RES-1. The length of fruit had no direct bearing among disease reaction groups. The maximum diameter of fruit was recorded in 16/BRBW RES-5 (7.50 $\mathrm{cm}$ ) and minimum in 16/BRBW RES-6 (3.00 $\mathrm{cm})$. The maximum variation in fruit weight $(58.00 \mathrm{~g}$ to $225.67 \mathrm{~g}$ ) among genotypes was observed. The highest fruit weight was recorded in 16/BRBW RES-5 followed by 16/BRBW RES-3 and the lowest fruit weight was observed in 13/BRBW/RES-3. Genotypes showing disease resistant reactions had comparatively lower mean fruit weight $(105.71 \mathrm{~g})$ ranging from $85.33 \mathrm{~g}$ to $126.67 \mathrm{~g}$ than other categorized groups. The maximum number of fruit per plant was produced by 13/BRBW/RES-3 (21.11) and the minimum 
was recorded in 2012/BRBW RES-7 (3.63). Wide variations in quantitative characters of brinjal genotypes tested previously in the Gangetic plains of West Bengal were also recorded by Das et al., (2010), Chattopadhyay et al., (2011), Shende et al., (2016) and Dutta et al., (2018). It was found that bacterial wilt resistance in brinjal is tightly linked with small fruit size. Scott et al., (2005) observed that bacterial wilt resistance originated from wild tomato, particularly Lycopersicum esculentum var. cerasiforme and $L$. pimpinellifolium and most tomato resistance sources tend to be small-fruited. Combining a complete set of desirable traits including horticultural characteristics and resistance to bacterial wilt into a single variety is rather challenging and sometimes can be contradictory (Guan et al., 2012). The close linkage between resistance against bacterial wilt in the Solanaceae and small fruit size is such an example (Louws et al., 2010).

\section{Genetic variability and heritability}

The genotypic coefficient of variation (GCV) helps to measure the range of genetic variability in a character and provides a measure to compare genetic variability present in various characters. Heritable variation cannot be measured using GCV alone. Estimates of $\mathrm{GCV}$ and PCV corresponded well for the expression of all characters under study indicating lesser influence of environment. PCV were slightly higher than the corresponding GCV indicating prevalence of environmental influence on expression of these traits (Table 5). However, the difference between PCV and GCV being very low for majority of the characters indicated the existence of inherent variability that remains unaltered by environmental conditions among genotypes, which is more useful for exploitation in selection and hybridization. High GCV and PCV values occurred for all characters indicating the potential of simple selection for improvement of these characters. These results are in conformity with Banerjee et al., (2018) and Parvati et al., (2018). A high proportion of GCV to PCV is desirable in selection because it indicates the traits are under genetic, rather than environmental control (Kaushik et al., 2007).

Heritability is of interest to plant breeders primarily as a measure of the value of selection for a particular character in various types of progeny, and as an index of transmissibility of characters from parent to offspring (Hayes et al., 1955). The concept of heritability is important to evaluate relative magnitude of effects of genes and environments on total phenotypic variability. For this reason, Burton (1952) stated that genetic variability, along with heritability, should be considered to assess the maximum and accurate effect of selection. Broad sense heritability value was highest for BWI $(99.69 \%)$ followed by fruit weight $(99.11 \%)$, number of fruits/plant (93.99\%), fruit yield/plant (90.26\%), fruit length $(88.74 \%)$ and fruit diameter $(60.12 \%)$ (Table 5). These observations corroborate the findings of Patel et al., (2004) for fruit length, fruit diameter, fruit weight and yield/ plant, Singh and Kumar (2005) for average fruit weight and fruit yield/ plant, Naliyadhara et al., (2007) for fruit diameter and fruit length, Muniappan et al., (2010) for fruit length, fruit breadth and average fruit weight, Rad et al., (2015) for fruit weight and fruit length. High magnitude of heritability was also reported for fruit diameter, fruit length, fruit weight and fruits/ plant by Kushwah and Bandhopadhya (2005), Ambade et al., (2013) and Manpreet et al., (2013) and Banerjee et al., (2018). High heritability for fruit diameter, fruit weight, number of fruits/ plant and yield/ plant was also reported by Babu and Patil (2005), Karak et al., (2012), Mili et al., (2014) and Parvati et al., (2018). High heritability indicates that the 
environmental influence is minimal on characters and these characters can be used for selection.

Genetic advance is improvement in performance of selected lines over the original population. It is not necessarily true that high heritability would always exhibit high genetic advance. For this reason, Johnson et al., (1955) stated that heritability in combination with genetic advance would be more reliable for predicting the effects of selection because genetic advance depends on the amount of genetic variability, magnitude of masking effect of genetic expression (environmental influence), and intensity of selection. In this present study, high magnitude (>20.00\%) of genetic advance as per cent of mean was recorded in characters BWI, fruit length, fruit diameter, fruit weight, number of fruits/plant, and fruit yield/plant (Table 5). Parvati et al., (2018) and Banerjee et al., (2018) also reported high genetic advance fruit length $(\mathrm{cm})$, fruit diameter $(\mathrm{cm})$, fruit weight $(\mathrm{g})$, number of fruits/plant, BWI $(\%)$ and fruit yield/plant (kg). High heritability coupled with high genetic advance was recorded in BWI (\%), fruit length $(\mathrm{cm})$, fruit diameter $(\mathrm{cm})$, fruit weight $(\mathrm{g})$, number of fruits/plant and fruit yield/plant $(\mathrm{kg})$ indicating that the selection among the genotypes can bring about significant improvement in the fruit yield and its component characters due to the presence of additive genes in traits. This result agreed with the findings of Ravali et al., (2017), Banerjee et al., (2018) and Parvati et al., (2018). High heritability estimates with high GA was also reported by Tirkey et al., (2018) and Prasad et al., (2004) for fruit yield and fruit weight; Babu and Patil (2008), Mili et al., (2014) and Sharma and Swaroop (2000) for fruit weight, fruits per plant and yield. Estimates of heritability with genetic advance are more reliable and meaningful than individual consideration of the parameters.

\section{Character association}

Most correlation coefficients at the genotypic level were greater than the corresponding phenotypic ones (Table 6). The higher values of genotypic, than phenotypic, correlation indicated that the genotypic effects were more important that environmental factors (Falconer 1988). In the presence of high environmental influence on expression of characters, there is the possibility of over estimation of the genotypic correlation coefficient. Only number of fruits/plant exhibited significantly positive genotypic correlation with fruit yield/plant. Positive correlation between fruit yield and number of fruits/plant was also recorded by earlier workers (Samlindsujin et al., 2017; Dutta et al., 2018; Banerjee et al., 2018). Percentage of bacterial wilt incidence was negatively correlated with fruit yield/plant. This indicated that lower the incidence of bacterial wilt will result in higher fruit yield/plant.

Fruit weight and number of fruit per plant had positive, direct effects on fruit yield/plant (Table 6), likely due to positive association with fruit yield/plant. Similar trend of findings were also obtained with other genotypes and environmental conditions by Thangamani and Jansirani (2012), Muniappan et al., (2010), Banerjee et al., (2018), Samlindsujin et al., (2017); and $\operatorname{Rad}$ et al., (2015) for average fruit weight in eggplant. Percentage of bacterial wilt incidence (BWI $\%$ ) had negative direct effects on fruit yield/plant due to negative association with fruit yield/plant. Direct effects of other characters were negligible. Direct selection could be beneficial for yield improvement since number of fruit/plant and fruit weight exhibited significant, positive, correlations with fruit yield/plant. The residual effect was low indicating inclusion of maximum important fruit yield/plant influencing characters in the analysis. 
Table.1 Disease rating scale of bacterial wilt disease in brinjal

\begin{tabular}{|c|l|l|}
\hline Scale & Reaction & Percentage of wilt \\
\hline $\mathbf{0}$ & Highly resistant (HR) & Plants did not show any wilt symptom \\
\hline $\mathbf{1}$ & Resistant (R) & $1-20 \%$ plants wilted \\
\hline $\mathbf{2}$ & Moderately resistant (MR) & $21-40 \%$ plants wilted \\
\hline $\mathbf{3}$ & Moderately susceptible (MS) & $41-60 \%$ plants wilted \\
\hline $\mathbf{4}$ & Susceptible (S) & $61-80 \%$ plants wilted \\
\hline $\mathbf{5}$ & Highly susceptible (HS) & More than $80 \%$ plants wilted \\
\hline
\end{tabular}

Table.2 Wilt reaction at periodic interval and fruit yield (q/ha) of brinjal genotypes

\begin{tabular}{|c|c|c|c|c|c|}
\hline \multirow[t]{2}{*}{ Genotypes } & \multicolumn{3}{|c|}{ Bacterial wilt incidence (\%) } & \multirow{2}{*}{$\begin{array}{c}\text { Reaction } \\
\text { at } 90 \\
\text { DAT }\end{array}$} & \multirow{2}{*}{$\begin{array}{c}\text { Fruit } \\
\text { yield } \\
\text { (q/ha) }\end{array}$} \\
\hline & 30 DAT & 60 DAT & 90 DAT & & \\
\hline 16/BRBW RES-1 & 0.00 & $8.33(16.78)$ & $13.89(21.88)$ & $\mathrm{R}$ & 278.09 \\
\hline 16/BRBW RES-2 & 0.00 & 0.00 & $8.33(16.78)$ & $\mathrm{R}$ & 308.64 \\
\hline 16/BRBW RES-3 & 0.00 & $2.79(9.62)$ & $11.11(19.47)$ & $\mathrm{R}$ & 293.21 \\
\hline 16/BRBW RES-4 & $16.67(24.10)$ & $47.21(43.40)$ & $63.89(53.06)$ & $S$ & 192.53 \\
\hline 16/BRBW RES-5 & $5.55(13.63)$ & $11.12(19.48)$ & $19.44(26.16)$ & $\mathrm{R}$ & 271.36 \\
\hline 16/BRBW RES-6 & $14.6(22.46)$ & $38.88(38.57)$ & $58.33(49.80)$ & MS & 212.1 \\
\hline 16/BRBW RES-7 & 0.00 & $5.55(13.63)$ & $16.67(24.10)$ & $\mathrm{R}$ & 296.42 \\
\hline 16/BRBW RES-8 & $5.55(13.63)$ & $15.29(23.02)$ & $22.22(28.12)$ & MR & 250.37 \\
\hline 13/BRBW/RES-1 & $4.76(12.60)$ & $20.95(27.24)$ & $35.10(36.33)$ & MR & 185.34 \\
\hline 13/BRBW/RES-2 & $1.90(7.92)$ & $11.43(19.76)$ & $19.00(25.84)$ & $\mathrm{R}$ & 245.51 \\
\hline 13/BRBW/RES-3 & $2.38(8.87)$ & $7.86(16.28)$ & $16.10(23.66)$ & $\mathrm{R}$ & 273.77 \\
\hline 13/BRBW/RES-4 & 0.00 & $6.67(14.97)$ & $14.90(22.71)$ & $\mathrm{R}$ & 292.33 \\
\hline SM-6-7 & 0.00 & $7.14(15.50)$ & $17.30(24.58)$ & $\mathrm{R}$ & 246.24 \\
\hline PPL & $11.43(19.76)$ & $28.1(32.01)$ & $57.10(49.08)$ & MS & 114.42 \\
\hline 2012/BRBW RES-1 & 0.00 & $1.60(7.27)$ & $15.08(22.85)$ & $\mathrm{R}$ & 225.34 \\
\hline 2012/BRBW RES-2 & $1.6(7.27)$ & $6.36(14.61)$ & $23.81(29.21)$ & MR & 120.27 \\
\hline 2012/BRBW RES-3 & 0.00 & $6.36(14.61)$ & $12.70(20.88)$ & $\mathrm{R}$ & 248.17 \\
\hline 2012/BRBW RES-4 & $2.38(8.87)$ & $8.74(17.20)$ & $24.60(29.73)$ & MR & 165.46 \\
\hline 2012/BRBW RES-5 & 0.00 & $1.60(7.27)$ & $6.35(14.60)$ & $\mathrm{R}$ & 251.51 \\
\hline 2012/BRBW RES-6 & $2.38(8.87)$ & $9.52(17.97)$ & $25.40(30.26)$ & MR & 198.11 \\
\hline 2012/BRBW RES-7 & 0.00 & $7.93(16.36)$ & $22.22(28.12)$ & MR & 152.98 \\
\hline Arka Nidhi (RC) & $2.79(9.62)$ & $12.50(20.70)$ & $16.67(24.10)$ & $\mathrm{R}$ & 241.46 \\
\hline Arka Kusumakar (SC) & $22.21(28.12)$ & $61.12(51.43)$ & $77.78(61.88)$ & $\mathrm{S}$ & 80.88 \\
\hline C.D. at $5 \%$ & 0.842 & 0.983 & 1.127 & - & 25.32 \\
\hline C.V. (\%) & 6.32 & 2.99 & 2.29 & - & 14.27 \\
\hline
\end{tabular}

*Figures in parentheses are angular transformed values.

$\mathrm{R}=$ Resistant $; \mathrm{MR}=$ Moderately resistant $\mathrm{MS}=$ Moderately susceptible; $\mathrm{S}=$ Susceptible

$\mathrm{RC}=$ Resistant Check; $\mathrm{SC}=$ Standard Cheek 
Table.3 Qualitative characters of 23 genotypes of brinjal genotypes

\begin{tabular}{|c|c|c|c|}
\hline Entries & Fruit colour & Calyx colour & $\begin{array}{l}\text { Fruit } \\
\text { shape }\end{array}$ \\
\hline 16/BRBW RES-1 & Purple & Green with purple mix & Oblong \\
\hline 16/BRBW RES-2 & Purple & Green & Long \\
\hline 16/BRBW RES-3 & Green with white stripes at basal end & Green & Oblong \\
\hline 16/BRBW RES-4 & Green & Green & Long \\
\hline 16/BRBW RES-5 & $\begin{array}{c}\text { Green with purple stripes at blossom } \\
\text { end }\end{array}$ & Green & Oblong \\
\hline 16/BRBW RES-6 & Light green & Green & Long \\
\hline 16/BRBW RES-7 & Purple & Green & Long \\
\hline 16/BRBW RES-8 & Green & Green & Long \\
\hline 13/BRBW/RES-1 & $\begin{array}{c}\text { Green with white stripes at blossom } \\
\text { end }\end{array}$ & Green & Long \\
\hline 13/BRBW/RES-2 & Purple & Green & Long \\
\hline 13/BRBW/RES-3 & Light green & Green & Long \\
\hline 13/BRBW/RES-4 & Greenish purple & Green & Long \\
\hline SM-6-7 & Whitish green & Green & Long \\
\hline Pusa Purple Long & Purple & Green & Long \\
\hline 2012/BRBW RES-1 & Purple & Green & Long \\
\hline 2012/BRBW RES-2 & Green & Green & Long \\
\hline 2012/BRBW RES-3 & $\begin{array}{c}\text { Green with white stripes at blossom } \\
\text { end }\end{array}$ & Green & Long \\
\hline 2012/BRBW RES-4 & Purple & Green & Long \\
\hline 2012/BRBW RES-5 & Purple & Green & Long \\
\hline 2012/BRBW RES-6 & Purple with greenish shade & Green & Long \\
\hline 2012/BRBW RES-7 & Purple & Green & Long \\
\hline Arka Nidhi & Blackish Purple & Green & Long \\
\hline Arka Kusumakar & Green & Green & Long \\
\hline
\end{tabular}


Table.4 Fruit characters of brinjal genotypes

\begin{tabular}{|c|c|c|c|c|}
\hline Entries & $\begin{array}{l}\text { Fruit length } \\
\text { (cm) }\end{array}$ & $\begin{array}{c}\text { Fruit } \\
\text { diameter }(\mathrm{cm})\end{array}$ & $\begin{array}{c}\text { Fruit } \\
\text { weight (g) }\end{array}$ & $\begin{array}{l}\text { Number of } \\
\text { fruits/plant }\end{array}$ \\
\hline \multicolumn{5}{|l|}{ Resistant group } \\
\hline 16/BRBW RES-1 & 9.52 & 5.85 & 85.33 & 18.32 \\
\hline 16/BRBW RES-2 & 18.46 & 3.80 & 92.67 & 20.49 \\
\hline 16/BRBW RES-3 & 10.32 & 6.10 & 120.67 & 10.93 \\
\hline 16/BRBW RES-5 & 12.54 & 7.50 & 125.52 & 9.71 \\
\hline 16/BRBW RES-7 & 19.27 & 4.28 & 126.67 & 10.49 \\
\hline 13/BRBW/RES-2 & 17.25 & 3.85 & 87.00 & 12.66 \\
\hline 13/BRBW/RES-3 & 12.90 & 3.20 & 58.00 & 21.11 \\
\hline 13/BRBW/RES-4 & 15.37 & 4.00 & 123.00 & 8.94 \\
\hline SM-6-7 & 18.20 & 4.25 & 115.00 & 9.98 \\
\hline 12/BRBW RES-1 & 20.01 & 4.35 & 120.00 & 10.44 \\
\hline 12/BRBW RES-3 & 16.80 & 5.10 & 120.00 & 8.41 \\
\hline 12/BRBW RES-5 & 23.25 & 3.14 & 95.00 & 12.79 \\
\hline Arka Nidhi & 14.37 & 4.62 & 105.33 & 10.84 \\
\hline Mean & 16.02 & 4.62 & 105.71 & 12.70 \\
\hline \multicolumn{5}{|c|}{ Moderately resistant group } \\
\hline 16/BRBW RES-8 & 17.85 & 3.87 & 115.33 & 9.76 \\
\hline 13/BRBW/RES-1 & 14.85 & 6.01 & 172.00 & 5.11 \\
\hline 12/BRBW RES-2 & 16.54 & 4.31 & 155.00 & 3.35 \\
\hline 12/BRBW RES-4 & 23.20 & 4.45 & 150.00 & 4.93 \\
\hline 12/BRBW RES-6 & 27.45 & 4.31 & 210.00 & 4.15 \\
\hline 12/BRBW RES-7 & 13.59 & 7.04 & 196.00 & 3.63 \\
\hline Mean & 18.91 & 5.00 & 166.39 & 5.16 \\
\hline \multicolumn{5}{|c|}{ Moderately susceptible group } \\
\hline 16/BRBW RES-6 & 14.36 & 3.00 & 145.30 & 6.53 \\
\hline Pusa Purple Long & 22.70 & 3.55 & 120.00 & 5.27 \\
\hline Mean & 18.53 & 3.28 & 132.65 & 5.90 \\
\hline \multicolumn{5}{|l|}{ Susceptible group } \\
\hline Arka Kusumakar & 14.25 & 3.87 & 93.00 & 3.85 \\
\hline 16/BRBW RES-4 & 14.65 & 3.57 & 162.33 & 5.35 \\
\hline Mean & 14.45 & 3.72 & 127.67 & 4.60 \\
\hline C.D. at 5\% & 2.53 & 1.20 & 15.32 & 3.27 \\
\hline C.V. (\%) & 7.52 & 4.37 & 11.20 & 10.34 \\
\hline
\end{tabular}


Table.5 Mean, range, and estimates of genetic parameters of brinjal genotypes

\begin{tabular}{|l|c|c|c|c|c|c|c|}
\hline Characters & Mean & Range & GCV & PCV & $\begin{array}{c}\text { GCV: } \\
\text { PCV } \\
(\%)\end{array}$ & $\begin{array}{c}\text { Heritability } \\
\text { in b.s (\%) }\end{array}$ & $\begin{array}{c}\text { GA as } \\
\text { \%ean }\end{array}$ \\
\hline $\begin{array}{l}\text { Fruit length } \\
\text { (cm) }\end{array}$ & 16.99 & $9.52-30.45$ & 27.30 & 28.98 & 94.20 & 88.74 & 52.98 \\
\hline $\begin{array}{l}\text { Fruit diameter } \\
\text { (cm) }\end{array}$ & 4.52 & $3.0-6.10$ & 24.90 & 32.12 & 77.54 & 60.12 & 39.78 \\
\hline $\begin{array}{l}\text { Fruit weight } \\
\text { (g) }\end{array}$ & 129.71 & $58.0-225.67$ & 38.86 & 39.04 & 99.55 & 99.11 & 79.70 \\
\hline $\begin{array}{l}\text { Number of } \\
\text { fruits/plant }\end{array}$ & 9.79 & $3.85-21.11$ & 50.40 & 51.98 & 96.95 & 93.99 & 100.65 \\
\hline $\begin{array}{l}\text { Bacterial wilt } \\
\text { incidence (\%) }\end{array}$ & 26.00 & $6.35-77.78$ & 41.21 & 41.27 & 99.84 & 99.69 & 84.76 \\
\hline $\begin{array}{l}\text { Fruit yield / } \\
\text { plant (kg) }\end{array}$ & 0.94 & $0.36-1.33$ & 27.76 & 29.22 & 95.00 & 90.26 & 54.32 \\
\hline
\end{tabular}

GCV= Genotypic Coefficient of Variance, PCV= Phenotypic Coefficient of Variance, GA= Genetic Advance

Table.6 Phenotypic and genotypic correlations among six characters and their direct effects on yield/plant

\begin{tabular}{|l|c|c|c|}
\hline Characters & rg & rp & Direct effects on yield/plant \\
\hline Fruit length $(\mathbf{c m})$ & -0.215 & -0.200 & -0.140 \\
\hline Fruit diameter $(\mathbf{c m})$ & 0.057 & 0.099 & -0.120 \\
\hline Fruit weight $(\mathbf{g})$ & -0.084 & 0.082 & 0.569 \\
\hline Number of fruits/plant & $0.552^{*}$ & $0.494^{*}$ & 0.738 \\
\hline Bacterial wilt incidence (\%) & $-0.741^{* *}$ & $-0.701^{* *}$ & -0.433 \\
\hline
\end{tabular}

$*$,** significant at $\mathrm{P}<0.05$ and $\mathrm{P}<0.01$, respectively.

$\mathrm{rg}=$ Genotypic correlation coefficient; $\mathrm{rp}=$ Phenotypic correlation coefficient.

Residual are 0.26906

Table.7 Cluster classification and source of collection of brinjal genotypes

\begin{tabular}{|c|l|}
\hline $\begin{array}{c}\text { Number of } \\
\text { clusters }\end{array}$ & \multicolumn{1}{|c|}{ Name of the genotype } \\
\hline I (2)* & Arka Kusumakar (SC), Pusa Purple Long \\
\hline II (4) & 16/BRBW RES-1,16/BRBW RES-2, 13/BRBW/RES-2, 2012/BRBW RES-5 \\
\hline III (5) & $\begin{array}{l}\text { 16/BRBW RES-7, 13/BRBW/RES-1, 13/BRBW/RES-4, 2012/BRBW RES-3, } \\
\text { 2012/BRBW RES-4 }\end{array}$ \\
\hline IV (2) & 16/BRBW RES-4, 16/BRBW RES-6 \\
\hline V (4) & 16/BRBW RES-3, 16/BRBW RES-5, 2012/BRBW RES-6, 2012/BRBW RES-7 \\
\hline VI (5) & $\begin{array}{l}\text { 16/BRBW RES-8, Arka Nidhi (RC), SM-6-7, 2012/BRBW RES-1, 2012/BRBW } \\
\end{array}$ \\
\hline VII (1) & RES-2 \\
\hline
\end{tabular}

*Figures in parentheses indicate number of genotypes 
Table.8 Inter-cluster distances of twenty five genotypes of brinjal

\begin{tabular}{|c|c|c|c|c|c|c|}
\hline Cluster & II & III & IV & V & VI & VII \\
\hline I & 57.302 & 78.942 & 37.219 & 120.097 & 50.502 & 68.99 \\
\hline II & & 75.004 & 55.125 & 121.161 & 25.654 & 33.456 \\
\hline III & & & 107.034 & 46.539 & 50.08 & 107.379 \\
\hline IV & & & & 151.405 & 64.743 & 46.213 \\
\hline V & & & & & 96.55 & 153.58 \\
\hline VI & & & & & & 57.803 \\
\hline
\end{tabular}

Table.9 Cluster means of six characters of brinjal genotypes

\begin{tabular}{|l|c|c|c|c|c|c|c|}
\hline Character & I & II & III & IV & V & VI & VII \\
\hline Fruit length $(\mathbf{c m})$ & 22.7 & 17.25 & 14.85 & 14.65 & 12.54 & 20.1 & 12.9 \\
\hline Fruit diameter $(\mathbf{c m})$ & 3.55 & 3.85 & 6.01 & 3.57 & 7.75 & 4.35 & 3.2 \\
\hline Fruit weight $\mathbf{( g )}$ & 108 & 87 & 172 & 62.33 & 225.67 & 120 & 58 \\
\hline Number of fruit per plant & 4.77 & 12.7 & 4.85 & 13.9 & 5.41 & 8.45 & 21.24 \\
\hline Bacterial wilt incidence (\%) & 57.1 & 19.0 & 35.1 & 63.89 & 19.44 & 15.08 & 16.10 \\
\hline Fruit yield per plant (kg) & 0.52 & 1.1 & 0.83 & 0.87 & 1.22 & 1.01 & 1.23 \\
\hline
\end{tabular}

Table.10 Results of principal component analysis (PCA) for four quantitative characters

\begin{tabular}{|l|c|c|c|}
\hline \multicolumn{1}{|c|}{ Principal Component (PC) } & Eigenvalue & \% Variance & \% Cumulative variance \\
\hline \multicolumn{2}{|c|}{ Eigenvalues and variance accounted for (\%) by } & PCA based on correlation matrix \\
\hline Fruit length (cm) & 2602.53629 & 87.76 & 87.76 \\
\hline Fruit diameter (cm) & 333.67528 & 11.25 & 99.01 \\
\hline Fruit weight (g) & 23.51928 & 0.79 & 99.80 \\
\hline Bacterial wilt incidence (\%) & 5.51366 & 0.19 & 99.99 \\
\hline
\end{tabular}

Table.11 Contribution of diverse traits in the principal components of brinjal

\begin{tabular}{|l|c|c|c|c|}
\hline Variables & $\mathbf{P C}_{\mathbf{1}}$ & $\mathbf{P C}_{\mathbf{2}}$ & $\mathbf{P C}_{\mathbf{3}}$ & $\mathbf{P C}_{\mathbf{4}}$ \\
\hline Factor loadings due to PCs with eigenvalues $>\mathbf{1}$ & \multicolumn{1}{l|}{} \\
\hline Fruit length (cm) & 0.010255 & 0.001888 & 0.964372 & 0.222814 \\
\hline Fruit diameter (cm) & 0.018005 & 0.000408 & -0.125907 & 0.086545 \\
\hline Fruit weight (g) & 0.988528 & 0.127445 & -0.025978 & 0.075273 \\
\hline Bacterial wilt incidence (\%) & -0.135365 & -0.985043 & -0.025579 & -0.103017 \\
\hline
\end{tabular}


Fig.1 Dendrogram of genotypes of brinjal following Ward's method. Genotypes are in left most columns

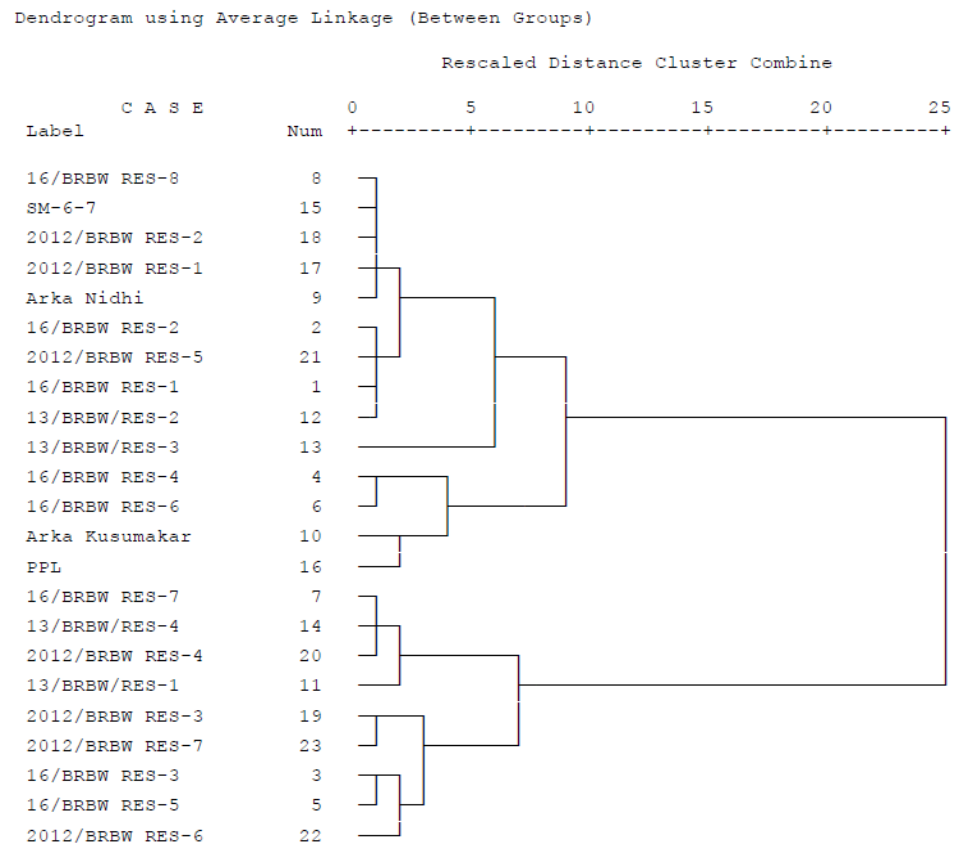

Fig.2 Scatter diagram of regression factor scores for the second and third components as determined by principal component analysis. Points in diagram closest to the intersection of 0 on the $\mathrm{X}$ - and Y-axes indicate similarity. Outliers on the X-axis, i.e., $1=16 / \mathrm{BRBW}$ RES-1, $2=$ 16/BRBW RES-1, 13 = 13/BRBW RES-3, 21 = 12/BRBW RES-5, 6 = 16/BRBW RES-6, 16 = PPL and $10=$ Arka Kusumakar, indicate diversity. Numbers correspond to name of the genotype (see Figure 1)

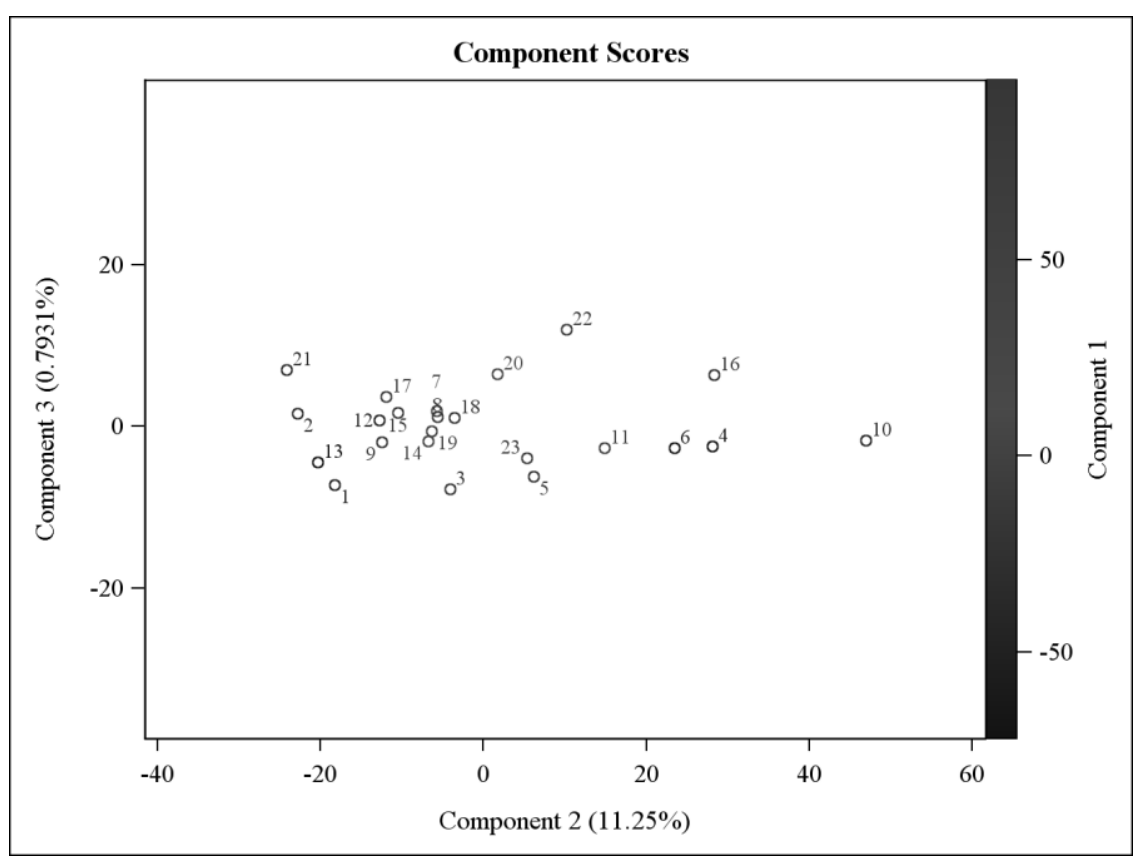




\section{Genetic diversity through multivariate} analysis

Assessment of divergence for a set of characters utilizing different multivariate analyses has been effectively utilized in vegetable crops with diverse breeding system (Murthy, 1979). Kalloo et al., (1980) suggested that the crosses between selected genotypes from widely separated clusters were most likely to give desirable recombinants. Based on the determination of divergence, all the twenty three genotypes could meaningfully be grouped into seven clusters (Table 7). Cluster III and VI had the maximum genotypes i.e. 5 genotypes in each clusters, Cluster II and VI comprised of 4 genotypes each, while Cluster I and Cluster IV had 2 genotypes each and cluster VII had 1 genotype.

The genetic divergence among brinjal genotypes through cluster analysis was reported by many workers (Begum et al., 2013; Banerjee et al., 2018; and Dutta et al., 2018). In general, the pattern of distribution of genotypes from diverse geographical region into different clusters was random. It might be due to free and frequent exchange of genetic materials among the farmers and breeders of different regions. Differential selection pressure according to regional preference also produced greater uniformity in the germplasm. The absence of relationship between genetic diversity and geographical distance indicated that forces other than geographical origin such as exchange of genetic stock, genetic drift, spontaneous mutation, natural and artificial selection were responsible for genetic diversity. Therefore, the selection of genotypes for hybridization should be based on genetic divergence rather than geographic diversity. Environmental influence on the composition of cluster was also recorded earlier in different selfpollinated crops like brinjal (Madhavi et al.,
2015), tomato (Peter and Rai, 1976), pea (Kalloo et al., 1980) and cowpea (Hazra et al., 1992).

The inter-cluster distance represents the index of genetic diversity among clusters (Table 8 ). The inter-cluster distance among 23 genotypes revealed that the minimum value was observed between Cluster I and IV (57.008) indicating close relationship among the genotypes included in these clusters. The maximum inter cluster value was observed between cluster V and VII (153.58) followed by 151.405 between Cluster IV and V, which indicated that the genotypes included in these clusters had the maximum divergence. Hence, intermating between the genotypes included in these clusters will be expected to give transgressive segregates in the advanced generation. Kalloo et al., (1980) suggested that the crosses between selected varieties from widely separated clusters were most likely to give desirable recombinants.

Cluster mean based estimations are very useful in targeting the genotypes for breeding programme, as they prevent the tedious efforts of screening the inferior germplasm lines. Hence, genotypes from desirable clusters could be directly used for final field evaluation in advanced breeding experiments. The character means were worked out for the genotypes falling in these seven clusters (Table 9) showed that the mean values of the clusters varied in magnitude for all the six characters. Cluster VII was the highest yielder followed by cluster V. Cluster VI had lowest bacterial wilt incidence while highest belongs to genotypes in cluster IV. Regarding fruit weight, cluster $\mathrm{V}$ showed highest performance followed by cluster III. Highest number of fruits per plant was produced in the genotypes belonging to cluster VII followed by the genotypes under cluster IV. These clusters could be regarded as useful sources of gene for important yield component traits. 
Hence, it can be suggested from the present study that a high yielding brinjal type with appreciable bacterial wilt disease tolerance could be bred by utilizing the genotypes from cluster VII and VI as parents in future breeding.

The PCA was performed to obtain a simplified view of the relationship between the characters fruit length, fruit diameter, fruit weight, bacterial wilt incidence and number of fruits per plant as shown in Table 10. Variable loadings for components PC1 (Fruit length), PC2 (Fruit diameter), PC3 (Fruit weight) and PC4 (Bacterial wilt incidence) were chosen because their eigenvalues exceeded 1.0 and explained $99.99 \%$ of the total variance (Table 11).

The first component (PC1) explained $87.76 \%$ of total accounted for variance in which an increase in fruit length $(\mathrm{cm})$ leads to increase in fruit diameter $(\mathrm{cm})$, fruit weight $(\mathrm{g})$, fruit and a decrease in percentage of bacterial wilt incidence (Table 11). The second component (PC2) explained an additional $11.25 \%$ of the variance in which an increase in fruit length (cm) was associated with increased fruit diameter, fruit weight along with decreased percentage of bacterial wilt incidence. The PCA was used to determine the strength of relationship between variables among brinjal genotypes by Ullah et al., (2014), Rad et al., (2015), Karim et al., (2016), Banerjee et al., (2018) and Dutta et al., (2018).There are no clear guidelines to determine the importance of a trait coefficient for each principal component. Johnson and Wichern (1988) regard a coefficient greater than half of the coefficient, divided by the square root of the standard deviation of the eigenvalue of the respective principal component, as significant.

High diversity occurred among genotypes along with strong relationships (Figure 1).
The scatter diagrams (Figure 2) indicated genotypes 16/BRBW RES-1, 16/BRBW RES1, 13/BRBW RES-3, 12/BRBW RES-5, 16/BRBW RES-6, PPL and Arka Kusumakar have distinct differences of genotypic characters and belong at the farthest distances from other genotypes. The remainder of genotypes had similar features forming a separate cluster.

From the plot of principal component and average values selection may be refined considering all 4 principal components, with 16/BRBW RES-2 being the best performing genotype having optimum combination of all variables, followed by genotypes 2012/BRBW RES-5 and 2012/BRBW RES-6 and can be used as improved genetic material for bacterial wilt resistant breeding and other important quantitative traits.

The traits under study exhibited high proportion of GCV to PCV which are under genetic, rather than environmental control, suggesting amenable to selection and predominantly controlled by additive genes. Fruit weight and number were identified as most important selection indices. The pattern of distribution of genotypes from diverse geographical regions into different clusters was random. Host plant resistance has been a major strategy for managing bacterial wilt in brinjal. Breeding for stable resistance is a challenge due to the fact that resistance in brinjal to bacterial wilt can be locationspecific, and incorporation of resistance into large-fruited varieties has also been a major challenge to breeders for coming years, suggesting linkage between small fruit size and bacterial wilt resistance. It is concluded from the present assessment that brinjal genotypes showed variations in their resistance response to $R$. solanacearum. None of the cultivars was immune or highly resistant to $R$. solanacearum. Based on $\mathrm{D}^{2}$ Statistic, PCA and average values three elite 
brinjal genotypes 16/BRBW RES-2, 2012/BRBW RES-5 and 2012/BRBW RES-6 possessed optimum combination of variables and could be utilized as donor parents in bacterial wilt disease resistant breeding.

\section{References}

Ambade, R.L., Sahu, M., Sahu, K.K. and Mehta, N. 2013. Heritability and genetic advance of yield and its components in brinjal (Solanum melongena L.). Asian $J$. Bio. Sci. 8 (2): 234-236.

Anonymous (2017) National Horticulture Board Database, Ministry of Agriculture and Farmers' Welfare, Government of India.

Babu, S.R. and Patil, R.V. 2005. Evaluation and variability studies of brinjal genotypes. Madras Agric. J. 92 (7-9).

Babu, S.R. and Patil, R.V. 2008. Characterization and evaluation of brinjal genotypes. Madras Agric. J. 95 (1-6): 1823.

Banerjee, S., Bisht, Y.S. and Verma, A. 2018. Genetic diversity of brinjal (Solanum melongena L.) in the Foot Hills of Himalaya. Int. J. Curr. Microbiol. App. Sci. 7(04): 3240-3248.

Begum, F., Islam, A.K.M.A., Rasul, M.G., Mian, M.A.K. and Hossain, M.M. 2013. Morphological diversity of eggplant (Solanum melongena L.) in Bangladesh. Emir. J. Food Agric. 25: 45-51.

Burton, G.W. 1952. Quantitative inheritance in grasses. Proceedings of the 6th International Grassland Congress. 1: 277-283.

Chattopadhyay, A., Dutta, S. and Hazra, P. 2011. Characterization of genetic resources and identification of selection indices of brinjal (Solanum melongena $\mathrm{L}$.) grown in eastern India. Vegetable Crops Research Bulletin. 74: 39-49.

Chattopadhyay, A., Dutta, S., Bhattacharya, I., Karmakar, K. and Hazra, P. 2007. Brinjal, In: Technology for Vegetable Crop Production, Published by All India Coordinated Research Project on
Vegetable Crops. Bidhan Chandra Krishi Viswavidyalaya, Nadia, West Bengal, India. pp. 218-230.

Chaudhary, D.R. and Sharma, S.D. 2000. Screening of some brinjal cultivars against bacterial wilt and fruit borer. Agri. Sci. Digest. 20: 129-130.

Das, C.R. and Chattopadhyay, S.B. 1953. Bacterial wilt on eggplant. Indian Phytopath. 8: 130-135.

Das, S., Mandal, A.B. and Hazra, P. 2010. Genetic diversity in brinjal genotypes under eastern Indian conditions. Indian J. Hortic. 67: 166-169.

Denny, T.P. 2000. Ralstonia solanacearum. A plant pathology in touch with its host. Trends Microbiol. 8: 486-489.

Dewey, D.R. and Lu, H.K. 1959. A correlation and path co-efficient analysis of component of crested wheat grass production. Agron J. 51: 515-518.

Dutta, T., Bhattacharjee, T., Banerjee, S., Maurya, P.K., Dutta, S. and Chattopadhyay, A. 2018. Studies on genetic variability and identification of selection indices in brinjal (Solanum melongena L.). J. Pharmacogn. Phytochem. 7(5): 1259-1264.

Elphinstone, J.G. 2005. The current bacterial wilt situation: A global overview. In: Allen C, Prior P, Hayward AC (Eds.). Bacterial Wilt Disease and the Ralstonia solanacearum Species Complex. American Phytopathological Society, St. Paul, Minnesota U.S.A. pp. 9-28.

Falconer, D.S. 1988. Introduction to quantitative Genetics. $3^{\text {rd }}$ ed. Longman, NewYork.

Fegan, M. and Prior, P. 2005. "How complex is the 'Ralstonia solanacearum species complex?' in Bacterial wilt Disease and the Ralstonia solanacearum Species Complex, eds C. Allen, P. Prior, and A. C. Hayward (Saint Paul, MN: APS Press). pp. 449-461.

Gavade, R.T. and Ghadage, B.A. 2015. Genetic variability, heritability and genetic advance in generation of brinjal (Solanum melongena L.). Bioinfolet. 12(1C): 325- 
328.

Geetha, P.T. and Peter, K.V. 1993. Bacterial wilt resistance in a few selected lines and hybrids of brinjal (Solanum melongena L.). J. Trop. Agric. 31: 274-276.

Gillings, M.R. and Fahy, P. 1994. "Genomic fingerprinting: towards a unified view of the Pseudomonas solanacearum species complex," in Bacterial wilt: the Disease and Its Causative Agent, Pseudomonas solanacearum, eds. A. C. Hayward and G. L. Hartman (Wallingford: CAB International). pp. 95-112.

Gopalakrishnan, C., Singh, T.H. and Artal, R.B. 2014. Evaluation of eggplant accessions for resistance to bacterial wilt caused by Ralstonia solanacearum (E.F. Smith) Yabuuchi. J. Hort. Sci. 9(2): 202-205.

Grimault, V. and Prior, P. 1990. Approach des mecanismes de resistance a fletrissement bactarian (Pseudomonas solanacearum E.F. Smith) Chez la tomato. In: Society Franchaise de phytopahologie, Zenus congress de la SFP, Montpellier. pp. 2830 .

Guan, W., Zhao, X., Hassell, R. and Thies J. 2012. Defense Mechanisms Involved in Disease Resistance of Grafted Vegetables. HortSci. 47(2): 164-170.

Hanson, P.M., Wang, J.F., Licardo, O., Hanudin, M.S.Y., Hartman, G.L., Lin, Y.C. and Chen, J.T. 1996. Variable reaction of tomato lines to bacterial wilt evaluated at several locations in Southeast Asia. HortSci. 31: 143-146.

Hayes, H.K., Immer, F.R. and Smith, D.C. 1955. Methods of plant breeding. McGraw-Hill Book Co. Inc. NY. pp. 5265.

Hayward, A.C. 1991. Biology and epidemiology of bacterial wilt caused by Pseudomonas solanacearum. Phytopatho. 29: 65-87.

Hazra, P. and Som, M.G. 1999. Technology for vegetable production and improvement. Naya Prokash, Kolkata, India.

Hazra, P., Som, M.G. and Das, P.K. 1992. Selection of parents for vegetable cowpea breeding by multivariate analysis. Veg.
Sci. 19: 166-173.

Hussain, M.Z. Rahman, M.A. and Bashar, M.A. 2005. Screening of brinjal accessions for bacterial wilt caused by Ralstonia solanacearum. Bangladesh J. Bot. 34: 5358.

Johnson, H.W., Rabinson, H.F. and Comstock, R.E. 1955. Estimates of genetic and environmental variability in soybean. Agron. J. 47: 314-318.

Johnson, R.A. and Wichern, D.W. 1988. Applied Multivariate Statistical Analysis. $2^{\text {nd }}$ Ed. John Wiley \& Sons Inc., New York.

Kalloo, G., Singh, V.P., Dudi, B.S. and Pratap, P.S. 1980. Analysis of variation and genetic diversity in garden pea (Pisum sativum L.). J. Res. Haryana. Agric. Univ. 10: 540-546.

Karak, C., Ray, U., Akhtar, S., Naik, A. and Hazra, P. 2012. Genetic variation and character association in fruit yield components and quality characters in brinjal [Solanum melongena L.]. J. Crop Weed. 8(1): 86-89.

Karim, M.R., Rahman, M.M. and Quamruzzaman, A.K.M. 2016. Genetic divergence in eggplant (Solanum melongena L.) genotypes. Bangladesh J. Agril. Res. 41(3): 433-439.

Kaushik, N., Kumar, K., Kumar, S. and Roy, S. 2007. Genetic variability and divergence studies in seed traits and oil content of Jatropha (Jatropha curcas L.) accessions. Biomass Bioenergy. 31: 497-502.

Kelman, A. 1953. The bacterial wilt caused by Pseudomonas solanacearum: A literature review and bibliography. North Carolina Agril. Expt Stn Technical bulletin 99: 194-197.

Kushwah, S. and Bandhyopadhya, B.B. 2005. Variability and correlation studies in brinjal. Indian J. Hortic. 62(2): 210-212.

Louws, F.J., Rivard, C.L. and Kubota, C. 2010. Grafting fruiting vegetables to manage soilborne pathogens, foliar pathogens, arthropods and weeds. Sci. Hort. 127: 127-146.

Lush, J.L. 1940. Intra-sire, correlation and 
regression of offspring on dam as a method of estimating heritability of characters. Proceedings of the American Society of Animal Production. 33: 293301.

Madhavi, N., Mishra, A.C., Pushpavathi. Y. and Kumari, V.L.P. 2015. Genetic diversity in brinjal (Solanum melongena L.) under temperate hills of Uttarakhand, India. Plt Arch 15 (2): 1107-1110.

Mahalanobis, P. 1936. On the generalized distance in statistics. Proceed Natl Inst Sci. India. 12: 49-55.

Manpreet, Dhatt A.S. and Singh, B. 2013. Variability, heritability and genetic advance in eggplant (Solanum melongena L.) during summer and rainy season. Asian J. Bio. Sci. 8(2): 200-204.

Mili, C., Bora, G.C., Das, B. and Paul, S.K. 2014. Studies on variability, heritability and genetic advance in brinjal (Solanum melongena L.) genotypes. Direct Res. J. Agric. Food Sci. 2(11): 192-194.

Mondal, B., Bhattacharya, I., Sarkar, A. and Khatua, D.S. 2013. Evaluation of local brinjal (Solanum melongena L.) germplasm for bacterial resistance. Int. J. Agril. Stat. Sci. 9: 709-716.

Muniappan, S., Saravanan, K. and Ramya, B. 2010. Studies on genetic divergence and variability for certain economic characters in eggplant (Solanum melongena L.). Electron J. Plant Breed. 1(4): 462-465.

Murthy, B.R. 1979. Selection of parental material, breeding methods and evaluation procedures in developing improved crop varieties. Indian J. Genet. 39: 305-315.

Naliyadhara, M.V., Golani, I.J., Mehta, D.R. and Purohit, V.L. 2007. Genetic variability, correlation co-efficient and path analysis in brinjal. Orissa J. Hort. 35(2): 92-96.

Panse, V.G. and Sukhtme, P.V. 1967. Statistical methods for agricultural workers. Indian Council of Agricultural Research, New Delhi. pp. 145.

Parvati, P., Jagadeesha, R.C., Satish, D., Venkateshalu and Mesta, R.K. 2018.
Genetic variability, heritability, genetic advance and genetic diversity analysis for yield, yield related components of brinjal [Solanum melongena L] genotypes. Int. J. Genet. 10(6): 460-463.

Patel, K.K., Sarnaik, D.A., Asati, B.S. and Tirkey, T. 2004. Studies on variability, heritability and genetic advance in brinjal (Solanum melongena L.). Agric. Sci. Digest. 24(4): 256-259.

Peter, K.N. and Rai, B. 1976. Genetic divergence in tomato. Indian J. Genet. 36: 379-383.

Ponnuswami, V. 1999. Studies on bacterial wilt resistance of selected eggplant accessories inoculated with Pseudomonas solanacearum PSSS97 for 30 days under growth room conditions at Asian Vegetable Research and Development Centre. Capsicum Eggplant Nwsl. 12: 9193.

Prasad, M., Mehta, N., Dikshit, S.N. and Nichal, S.S. 2004. Genetic variability, genetic advance and heritability in brinjal (Solanum melongena L.). Orissa J. Hort. 32(2): 26-29.

Prior, P., Grimault, V. and Schmit, J. 1994. Resistance to bacterial wilt (Pseudomonas solanacearum) in tomato: present status and prospects. In: Hayward, A.C., Hartman, G.L., (eds.). Bacterial wilt: the disease and its causative agent, Pseudomonas solanacearum. CAB International, Wallingford. pp. 209.

Rad, M.R.N., Poodineh, M., Ghalandarzehi, A. and Abkhoo, J. 2015. Variability, heritability and association analysis in eggplant (Solanum melongena L.). ARPN J. Agri. Biol. Sci. 10(12): 464-468.

Rahman, M., Farjana, A.K.M., Hussain, A. and Lutfunnaher, L. 2011. Screening of different eggplant cultivars against wilt disease caused by fungi, bacteria and nematodes. J. Exptl. Sci. 2: 6-10.

Rai, P.V., Shivappasetty, K.K.A. and Vasanthasetty, K.P. 1975. Bacterial wilt of petunia and its source of inoculum. Curr. Res. 4: 173-174.

Rao, C.R. 1952. Advance Statistical Methods 
in Biometrics. John Willey and Sons Inc., New York. pp. 390.

Rao, M.V.B., Sohi, H.S. and Vijay, O.P. 1976. Reaction of some varieties of brinjal to Pseudomonas solanacearum. Veg. Sci. 3: 61-64.

Ravali, B., Reddy, K.R., Saidaiah, P. and Shivraj, N. 2017. Genetic diversity in brinjal (Solanum melongena L.). Int. J. Curr. Microbiol. Appl. Sci. 6(6): 48-54.

Salgon, S., Jourda, C., Sauvage, C., Dauna, M.C., Reynaud, B., Wicker, E. and Dintinger, J. 2017. Eggplant resistance to the Ralstonia solanacearum species complex involves both broad-spectrum and strain-specific quantitative trait loci. Front Plant Sci. 8: 828. doi: 10.3389/fpls.2017.00828.

Samlindsujin, G., Karuppaiah, P. and Karavannan, K. 2017. Genetic variability and correlation studies in brinjal (Solanum melongena L.). Indian J. Agric. Res. 51(2): 112-119.

Scott, J.W., Wang, J.F. and Hanson, P.M. 2005. Breeding tomatoes for resistance to bacterial wilt, a global view. Acta Hortic. 695: 161-172.

Sharma, T.V.R.S. and Swaroop, K. 2000. Genetic variability and character association in brinjal (Solanum melongena L.). Indian J. Hort. 57(1): 5965.

Shende, V.D., Chattopadhyay, A., Yadav, Y., Seth, T. and Mukherjee, S. 2016. Breeding round fruited brinjal for export trade from eastern part of India. Agric. Res. 5(3): 219-229.

Singh, O. and Kumar, J. 2005. Variability, heritability and genetic advance in brinjal. Indian J. Hort. 62(3): 265- 267.

Sivasubramanyam, M.S. and Menon, M.P. 1973. Path analysis of yield components in rice. Madras Agric. J. 60(9/12): 12171221.

Smith, E.F. 1920. Brown rot of Pseudomonas solanacearum. An introduction to bacterial diseases of plants. W.B. Saunder Co., Phildelphia, USA. pp. 177-201.

Thangamani. C. and Jansirani, P. 2012.
Correlation and path coefficient analysis studies on yield and attributing characters in brinjal (Solanum melongena L.). Electron J. Plant. Breed. 3(3): 939-944.

Tirkey, M., Saravana, S. and Pushpa lata. 2018. Studies on variability, heritability and genetic advance for yield and its attributes in brinjal (Solanum melongena L.). J. Pharmacogn. Phytochem. SP1: 11811183.

Ullah, S., Usman, I., Tahir, I., Najeebullah, M. and Shahid, N. 2014. Association and genetic assessment in brinjal. European $J$ Biotechnol. Biosci. 2: 41-45.

USDA 2003 Biological control of Fusarium wilt and other soil-borne pathogenic fungi. http://www.ars.usda.gov/research/projects /projects.htm?ACCN_NO=406590\&fy=2 003.

Vasse, J., Danoun, S. and Trigalet, A. 2005. Microscopic studies of root infection in resistant tomato cultivar Hawaii 7996. In: Allen, C., Prior, P. and Hayward, A.C. (eds.). Bacterial wilt disease and the Ralstonia solanacearum species complex. APS Press, St. Paul, Minnesota, USA, pp. 285.

Ward, J.H. 1963. Hierarchial grouping to optimize an objective function. $J$. Am. Stat. Assoc. 58: 236-244.

Wicker, E., Grassart, L., Coranson-Beaudu, R., Mian, D., Guilbaud, C. and Fegan, M. 2007. Ralstonia solanacearum strains from martinique (French West Indies) exhibiting a new pathogenic potential. Appl. Environ. Microbiol. 71: 6790-6801.

Winstead, N.N. and Kelman, A. 1952. Inoculation techniques for evaluating resistance to Pseudomonas solanacearum. Phytopatho. 42: 628-634.

Yabuuchi, E., Kosako, Y., Yano, I., Hota, H. and Nishiuchi, Y. 1995. Transfer of two Burkholderia and an Alcaligenes species to Ralstonia gen. Nov.: Proposal of Ralstonia pickettii (Ralston, Palleroni and Doudoroff 1973) comb. Nov., Ralstonia solanacearum (Smith 1896) comb. Nov. and Ralstonia eutropha (Davis 1969) comb. Nov. Microbiol. Immunol. 39(11): 
897-904.

Yuliar, Nion, Y.A. and Toyota, K. 2015. Recent trends in control methods for bacterial wilt diseases caused by Ralstonia solanacearum. Microbes. Environ. 30(1): $1-11$.

\section{How to cite this article:}

Lalramhlimi, B., Tithi Dutta, Imtinunsang Jamir, Praveen Kumar Maurya, Tridip Bhattacharjee, Swadesh Banerjee, Soumitra Chatterjee, Asit Kumar Mandal and Arup Chattopadhyay. 2019. Choosing of Brinjal Parents for Future Breeding Aiming at Bacterial Wilt Disease Tolerance. Int.J.Curr.Microbiol.App.Sci. 8(06): 2370-2390.

doi: https://doi.org/10.20546/ijcmas.2019.806.283 